\title{
1
}

\section{Legal Aid in the Nordic Countries}

\section{Ole Hammerslev and Olaf Halvorsen Rønning}

The Nordic countries are among the highest spenders in Europe on legal aid, which provides people with legal services when they cannot otherwise afford legal assistance. Figures from 2012 provided by the European Commission for the Efficiency of Justice CEPEJ (2014) show that, of 47 European countries, Norway spends the most on legal aid per inhabitant, Sweden comes sixth, Denmark eighth, Finland tenth, and Iceland eleventh (for a full discussion, see Chap. 10). However, like many other Western European countries, Nordic countries also face political demands for cost savings, particularly in the face of the years of austerity following the 2008 financial crisis that impacted European welfare states. The welfare state was challenged by the entry of private actors into domains that

\section{O. Hammerslev ( $\bowtie)$}

Department of Law, University of Southern Denmark, Odense M, Denmark

Department of Criminology and Sociology of Law, University of Oslo,

Oslo, Norway

O.H. Rønning

Department of Criminology and Sociology of Law, Faculty of Law, University of Oslo, Oslo, Norway 
traditionally belonged to the state, and by market-orientated reforms partly inspired by neo-liberal ideas (Bonoli and Natali 2012; Kvist and Greve 2011). This has affected legal aid in Nordic countries, just as it has in countries throughout the world, where legal aid systems are challenged by funding cuts, and there are demands for the setting of new priorities when limited funds are available.

The most prominent of such developments has been the recent changes in England and Wales, which has seen dramatic cuts in funding that affect both the supply of legal aid, and those legal professionals providing it. Studies of English legal aid lawyers show how new public management focuses on efficiency, cost control, and external monitoring through various forms of quality assurance measurements and guidelines (Sommerlad 2001; Sommerlad and Sanderson 2013; Sommerlad and Wall 1999). One major effect of all this, Sommerlad argues, is that legal aid lawyers, once seen as moral or political lawyers-who, as Sarat and Scheingold (1998, p. 3) point out - help raise the moral status of the legal profession by reconnecting law and morality, and by manifesting 'the idea that lawyering is a "public profession" - become a group of lawyers with low morale that damages the political project they set out to defend, namely that of empowering their clients and countering social injustice. Legal aid lawyers are downgraded in the legal hierarchy, are stressed by increasing workloads, earn less, and, finally, turn into burned-out, disillusioned welfare workers (Sommerlad 2001). Meanwhile, Eastern European countries also face challenges in developing legal aid schemes, mainly due to massive underfunding. Instead, legal clinics are linked with law schools and legal education (cf. for instance, Barendrecht et al. 2014, p. 82; Piana et al. 2013). The USA fares no better, struggling with an underdeveloped legal aid scheme for criminal cases, and with a civil legal aid system consisting of a wide variety of programmes beset with funding issues, and problems to do with federal versus state provision of legal aid (Houseman 2015). In Australia, there is a diverse set of legal aid initiatives, and severe challenges as regards provision for the indigenous population, and for rural areas, together with the problem of severe financial constraints (Hunter et al. 2009). Countries such as China and Japan seem to have introduced extensive legislation on legal aid but are experiencing challenges about putting it into practice (Qin and Tang 2013). In Brazil, there has been growing interest in the right to legal aid provided by the 
state, but, so far, it is still charitable organisations that seem to provide most of the legal aid (Alves 2014).

In this book, we set out to examine and compare civil legal aid in Nordic countries, as seen in relation to welfare state reforms, to determine if a unique model of Nordic legal aid exists. The Nordic welfare state model, common to all Nordic countries, is characterised by universal state-regulated welfare schemes, which give all citizens the right to assistance when they have various kinds of health or social problems. With the development of the Nordic welfare states after World War Two, the process of juridification accelerated, as legislation ensuring people's rights to welfare expanded. The growing complexity of welfare rights and regulation, as well as increasing bureaucracy, meant that ordinary people, especially poor people, had difficulty claiming their rights, both from the public administration and in the courts. Substantial legal aid schemes were developed to help people claim these rights, and in the Nordic countries legal aid came to be considered as part of the universal welfare ideology.

Nordic research on legal aid has most often been carried out against the backdrop of the ideology of universal welfare: researchers have generally considered legal aid as no different from traditional welfare state social support schemes, such as health care and social security, even though the market for legal services has been based primarily on market premises (Johnsen 1987). Though limited, Nordic legal aid research flourished in the 1970s and developed hand-in-hand with the emergence of new legal aid clinics in Norway and Denmark that were critical of public legal aid that was failing to satisfy unmet legal need among disadvantaged groups in society.

\section{Nordic Legal Aid Research}

With the strong social commitment of the 1970s, and the turn towards critical scholarship, if not Marxism, research inspirations and interests varied markedly in different Nordic countries. It was only in Norway that legal aid research developed into a strong field of socio-legal research in this decade, with pioneers such as Vilhelm Aubert, Thomas Mathiesen, Kristian 'Kikki' Andenæs, Torstein Eckhoff, and Jon T. Johnsen, in the Faculty of Law of the University of Oslo. They were inspired by US 
sociology, the sociology of law, and by cause lawyering (Mathiesen 2001). They succeeded in establishing several so-called action research projects that sought to combine scientific knowledge with practical action (Hammerslev and Mathiesen 2013). These projects had several aims. First, they established legal aid clinics in which law students gave free outreach legal aid to marginalised citizens. Not only did people in need get free legal advice, but law student volunteers got practical experience as a part of their education. Another aim was to document which types of legal need existed, and how social structures impacted different classes unevenly, so that the aid could be improved, and knowledge could be used to benefit those in need. They established attractive kinds of legal clinics in which future high profile lawyers and judges worked in during their studies. Through their visibility and use of academic capital, they successfully set the agenda on legal aid: factors that still make the legal clinic Juss-Buss an important and visible player in Norway (see Chap. 7). In Denmark, as in Finland, critical legal scholars were more concerned with changing social conditions for marginalised people by means of theoretical analysis of the law, and of the very concept of law (Hammerslev and Madsen 2014; Hammerslev and Madsen 2013). There were a few studies of legal aid, and some Danish research on various issues in Greenland, but their engagement with legal aid issues was not sufficient to make legal aid paradigmatic as a research topic, or as an important element in the public discourse, as had happened in Norway.

Noting the development of extensive welfare legislation giving all citizens rights in increasing areas, a series of Norwegian studies in the 1970s and 1980s examined the latent need for legal aid among marginalised people (Eidesen et al. 1975; Eskeland and Finne 1973; Johnsen 1994, 1987; Andenæs et al. 2005). Legal aid was defined thus: 'Aid which one person receives from another ... when the aid worker has legal knowledge that can potentially have an impact on obtaining a desired result.' (Eskeland 1975, p. 12, our translation).

In several studies during the 1970s, including work on immigrant workers, Norwegian Romani, and the homeless, Norwegian scholars found that the need for legal aid was determined by social structures in industrialised society: everyone has a need for legal aid but the system for 
accessing legal assistance is uneven. The higher your position in the social hierarchy, the greater is the availability of legal aid-which means that the well-off, and companies, can have their needs met by the wide variety of legal services offered on the free market, while the more disadvantaged you are, less is available, and the more difficult it is to access legal aid. Mathiesen concluded that the need for legal aid was greater the lower the class one belonged to, and that the 'lumpenproletariat' had an especially acute need for legal aid in the areas of tax law, social security law, and the law on rent-core areas of the welfare state (Mathiesen 1975, p. 188). This showed that legal aid was symptomatic of social structures: on the one hand, even though welfare rights relate to basic subsistence, citizens are more likely to claim their rights the higher in the social hierarchy they are; on the other hand, many problems that the law is designed to solve cannot be solved by the law, since they arise from concrete difficult life situations (Eskeland and Finne 1973; Mathiesen 1975; Albrechtsen 1975). These studies generally followed work done in the USA and the UK (Hammerslev 2016; Smith 1919, Clark and Corstvet 1938; Pleasence et al. 2001; Dalberg-Larsen 1977; Abel-Smith et al. 1973).

Through the legal clinics, researchers were able to examine various barriers to legal aid, and the way legal aid, including outreach legal aid, was delivered; they were also in a position to make recommendations on the organisation of legal aid institutions. One reason why the law fails to give the legal protection it is designed to provide, it was argued, is the fact that welfare law is often written in difficult language, so that the rules are hard to understand for any lay person-and even more so for marginalised people, who often have little education. Another reason was that marginalised people could not afford legal assistance if it was not free (Sejr 1977). As society becomes ever more complex, and the amount of legislation becomes ever greater, this creates legal insecurity. To this should be added the increasing use of framework acts that delegate authority to public authorities for making decisions. The decisions and discretion of public authorities may well become dependent on financial or political criteria, making the most marginalised even more vulnerable (Beck and Sejr 1977, p. 213; see also Papendorf 2012).

Despite the existence of outreach legal aid for less well-off groups, there were barriers that prevented it reaching the target groups, because 
of the way aid was organised, and because of the target groups' lack of knowledge of legal aid, and their distrust of legal aid lawyers. To meet the needs of the most disadvantaged groups in society, Sejr (1977) concludes, legal aid ought to be delivered through informal institutions that have a close connection to local communities, and by means of outreach work. Institutions should be independent of the state and staffed by lawyers but should also have links with social workers and psychologists, because legal problems are often linked to other issues. Furthermore, legal aid should be free, and information about it should be made more available to target groups (Beck and Sejr 1977, p. 217). Legal aid was seen as a way to strengthen the rule of law and to enable citizens to take part in democratic decision-making processes (Beck and Sejr 1977, p. 219; see also Papendorf 2012).

Despite considerable state expenditure on legal aid, these early studies set the agenda for later legal aid research through their critical approach to the organisation of legal aid and the apparent unmet legal need among the poorest groups in society. In general, Nordic studies were characterised by an optimistic view of the law, and of free legal aid as the solution to various problems of less well-off groups in society. The studies assumed that they could uncover a latent-but real-need for legal assistance among certain groups of citizens. Thus, against a background of assumptions about a universal welfare state, unmet legal need in the Nordic populations is well documented (Dalberg-Larsen and Kristiansen 2014; Kristiansen 2013, 2009; Graver et al. 2001; Juss-Buss 2001; Juss-Buss and Rønning 2011). However, these studies rarely consider the normative side of their methodological approach. Behind the assessment of legal need was the assumption that people should use lawyers to solve their problems, and that when they did not use lawyers or other advisors, this constituted 'unmet legal need'. This made it easy to argue that further public funds were necessary (see also Pleasence et al. 2001). Hidden behind discussions of methods and empirical findings is the failure of the studies to recognise that, as Lewis (1973) pointed out: 'defining something as a legal problem is not a statement of fact, but a normative statement about how a problem ought to be solved.' The focus of the research, and the research design, has an embedded normativity (Habermas 1972). 


\section{Purpose of the Book}

As illustrated by the literature review above, Nordic research on legal aid has not taken recent welfare state changes into consideration, nor have there been any comparative studies of all the Nordic countries. To serve several purposes, this volume therefore takes a different approach from that of traditional Nordic studies.

First, through chapters on individual countries, it seeks to compare all Nordic legal aid schemes-i.e., those of Denmark, Norway, Sweden, Finland, and Iceland - and to relate legal aid developments to those in the welfare states. The chapters explore some general questions about how legal aid schemes in the Nordic countries are organised and how they function. To what extent do the schemes match welfare state ideology, and are they changing alongside the changes in the welfare state?

Second, through discussions of the European 'access to justice perspective' set against the USA use of legal clinics, Chaps. 10, 11, and 12 examine the uniqueness of Nordic legal aid in a wider perspective. The overarching question is whether we can identify a Nordic model of legal aid. Through comparison of approaches within the Nordic countries, and the positioning of Nordic legal aid in the wider world, the conclusion will compare the Nordic schemes, their differences and similarities-and discuss if the Nordic welfare state approach to legal aid is unique.

Budget cuts also give rise to questions about how to design efficient legal aid programmes, and make alternative legal aid schemes more interesting: throughout the world there is a wide variety of alternative programmes exploring new ways of providing legal aid. As discussed above, Nordic legal aid research has also focused on, and recommended, the provision of alternative forms of legal aid. Thus a third purpose of this volume is to explore and discuss how legal aid institutions in the contemporary Nordic welfare states are organised and how they work. Chaps. 7 , 8 , and 9 examine some of the most notable alternative legal aid programmes in the Nordic countries: Juss-Buss, the Danish organisation The Street Lawyers, and various mentoring programmes for ex-prisoners. The aim of these case studies is to discuss alternative legal aid initiatives, and examine how the various programmes reach their target groups and help turn social problems into legal cases through legal aid in-to adopt the 
notion of Felstiner et al. (1980) —a naming, blaming, claiming process (for earlier studies discussing this process see, e.g., Carlin and Howard 1964-1965, p. 424; Johnsen 1987; Olesen et al. 2016, 2017).

\section{Outline}

Following the introduction, Chaps. 2, 3, 4, 5, and 6 will describe the national legal aid systems of the five Nordic countries. In this section, the public, state-organised legal aid schemes will be analysed, together with other notable legal aid initiatives in particular countries. The Norwegian legal aid scheme, as examined by Olaf Halvorsen Rønning, is largely based upon a well-funded public legal aid 'judicare' scheme. However, it is traditionally organised, with private-practice lawyers as the main providers, so it fails to fully meet some legal needs, especially those of disadvantaged groups. The public legal aid scheme is therefore complemented by a few high-capacity, outreach-focused legal aid initiatives directed at certain disadvantaged groups. These programmes are to some extent state-funded but are otherwise independent, and are connected to a Norwegian tradition of legal aid research and policy. The Swedish legal aid scheme-as described by Isabel Schoultz- has undergone a transformation: it used to be a public scheme comparable with Norway but now relies mainly on commercial legal aid insurance. Few alternative legal aid programmes exist. Insurance schemes mostly cover legal representation in trials, not legal advice or representation. Antti Rissanen examines legal aid in Finland. The Finnish legal aid scheme is perhaps the one most in tune with a welfare state ideology, as state-funded legal aid offices are the backbone of the scheme. It covers all legal problems, and has generous financial eligibility criteria. If necessary, the public legal aid offices can call on judicare lawyers. The Finnish legal aid system seems to work well but concerns have been raised that this system, too, will face more restrictions in coming years. The Danish legal aid scheme, as analysed by Bettina Lemann Kristiansen, has a mix of legal aid offices and judicare lawyers. The legal aid offices, organised by a private lawyers' and volunteers' initiative, but partly funded by the state, provide most of the legal advice, while legal 
representation, particularly in the courts, is provided by lawyers. The trend is now to cut expenditure on legal aid and on legal advice in particular. This is raising concerns about the accessibility of the legal aid system. Hildur Fjola Antonsdottir examines Icelandic legal aid. At present the Icelandic legal aid scheme is being affected by the financial crisis. It is based on a judicare model, with a measure of discretion regarding eligibility criteria, but the scheme is mostly limited to legal representation. The lack of accessible legal advice and information remains a concern.

After this analysis of the general legal aid systems, seen from a national perspective, Chaps. 7, 8, and 9 are devoted to in-depth case studies of particularly interesting examples of legal aid in the different countries. From Norway, there is a chapter by Ole Hammerslev, Annette Olesen, and Olaf Halvorsen Rønning on Juss-Buss, a student-run legal aid clinic. The establishment of the clinic was closely connected with pioneering legal aid research in Norway in the 1970s, and it is still in operation. JussBuss provides outreach legal aid to disadvantaged groups, such as prisoners and migrant workers, who are insufficiently covered by public schemes. Stine Piilgaard Porner Nielsen and Ole Hammerslev examines Gadejuristen [The Street Lawyers], which is a project in Denmark providing legal aid to vulnerable groups on the streets, such as drug addicts and sex workers. It is based on a holistic and novel outreach idea, and provides social and legal aid in an informal manner. The legal needs of ex-prisoners, and how the legal aid system functions in relation to them, are examined by Annette Olesen in the last chapter of this section. With background in the above-mentioned notion of Felstiner et al. 1980) of a naming, blaming, claiming process, which stresses how legal cases can emerge and transform, it highlights the inadequacy of the legal aid scheme to cope with the complexities of the legal problems prisoners face, and points to the need for more cross-functional legal aid programmes.

The final section, Chaps. 10, 11, and 12, will help contextualise the studies of the Nordic legal aid schemes. Johnsen's chapter on the Nordic model of legal aid in Europe compares the Finnish and Norwegian models of legal aid, and analyses them in relation to the ideologies of the welfare state, and against the background of European human rights. On the basis of theoretical perspectives on juridification, in particular in relation 
to Habermasian theories on the development of law in welfare states, Papendorf discusses the scope for disadvantaged groups to mobilise the law. Wilson discusses the differences between the USA and the European traditions of legal aid clinics, pointing out the current development of clinical legal education that is taking place in Europe.

The concluding chapter, Chap. 13, compares and analyses the legal aid systems in the Nordic countries, particularly in relation to the changes taking place in the welfare states, and discusses whether there is a unique Nordic model of legal aid.

\section{References}

Abel-Smith, B., Zander, M., \& Brooke, R. (1973). Legal problems and the citizen: A study in three London boroughs. London: Heinemann.

Albrechtsen, E. H. (1975). Om advokater og advokatsøking. In A. Eidesen, S. Eskeland, \& T. Mathiesen (Eds.), Rettshjelp og samfunnsstruktur (pp. 23-71). Oslo: Pax.

Alves, C. F. (2014). Contemporary challenges to legal aid in Brazil and England: Comparative perspectives on access to justice. Amicus Curiae, 98, 22-25.

Andenæs, K., Olsen-Nalum, H., Røed, M., \& Westlund, J. (2005). Kontoret for fri retshjalp: Retshjalp til ubemidlede: evaluering av en Oslo-institusjon gjennom 112 ar. Oslo.

Barendrecht, M., Kistemaker, L., Scholten, H. J., Schrader, R., \& Wrzesinska, M. (2014). Legal aid in Europe: Nine different ways to guarantee access to justice? Amsterdam: Ministerie van Veilgheid en Justitie.

Beck, S., \& Sejr, L. (1977). Retshjælpsbehov og retshjælpstilbud-en afsluttende teoretisk og retspolitisk diskussion.’. In L. Sejr (Ed.), Retshjalp $i$ et lokalomrade (pp. 201-221). Aarhus: Aarhus Universitet.

Bonoli, G., \& Natali, D. (Eds.). (2012). The politics of the new welfare state. Oxford: Oxford University Press.

Carlin, J. E., \& Howard, J. (1964-1965). Legal representation and class justice. UCLA L. Rev., 12, 381-437.

Clark, C. E., \& Corstvet, E. (1938). The lawyer and the public: An A.A.L.S survey. The Yale Law Journal, 47, 1972-1993.

Dalberg-Larsen, J. (1977). Retshjælpsproblemer i et historisk perspektiv. Om behovet for retshjælp og om ideologi, praksis og forsning på retshjælpsområdet. In L. Sejr (Ed.), Retshjalp i et lokalområde (pp. 6-42). Aarhus Universitet. 
Dalberg-Larsen, J., \& Kristiansen, B. L. (2014). Lovene og livet: En retssociologisk grundbog. København: Jurist- og Økonomforbundets Forlag.

Eidesen, A., Eskeland, S., \& Mathiesen, T. (1975). Rettshjelp og samfunnsstruktur. Oslo: Pax Forlag.

Eskeland, S. (1975). Innledning. In A. Eidesen, S. Eskeland, \& T. Mathiesen (Eds.), Rettshjelp og samfunnsstruktur (pp. 10-22). Pax Forlag: Oslo.

Eskeland, S., \& Finne, J. (1973). Rettshjelp. Oslo: Pax.

European Commission for the Efficiency of Justice. (2014). European judicial systems. Efficiency and quality of justice. Edition 2014 (2012 data). CEPEJ. Council of Europe. Strasbourg (CEPEJ 2014).

Felstiner, W. L. F., Abel, R. L., \& Sarat, A. (1980). The emergence and transformation of disputes: Naming, blaming, claiming. Law \& Society Review, 15(3/4), 631-654.

Graver, A. B., Skaug V., Strålberg, R., \& Tangen, B. (2001). Rettshjelp 2001: Behovet for rettshjelp $i$ Oslos befolkning - deriblant et utvalg innvadrekvinner. Universitetet i Oslo, Institutt for kriminologi og rettssosiologi.

Habermas, J. (1972). Knowledge and human interests. Boston: Beacon Press. Hammerslev, O. (2016). Retshjælpsforskning. In H. V. G. Pedersen (Ed.), Juridiske emner ved Syddansk Universitet 2015 (pp. 339-348). Jurist- og Økonomforbundets Forlag: København.

Hammerslev, O., \& Madsen, M. R. (Eds.). (2013). Retssociologi. København: Hans Reitzels Forlag.

Hammerslev, O., \& Madsen, M. R. (2014). The return of sociology in Danish socio-legal studies: A survey of recent trends. International Journal of Law in Context, 10(3), 397-415.

Hammerslev, O. \& Mathiesen, T. (2013). Marxistisk retssociologi. In O. Hammerslev \& R.M. Madsen (Eds.), Klassisk og moderne retssociologi. Centrale temaer og tekster. København: Hans Reitzels Forlag.

Houseman, A. W. (2015). Civil legal aid in the United States: An update for 2015. Washington, DC: National Equal Justice Library.

Hunter, R., Banks, C., \& Giddings, J. (2009). Australian innovations in legal aid services: Lessons from an evaluation study. In P. Pleasence \& N. J. Balmer (Eds.), Reaching further: Innovation, access and quality in legal services. London: TSO.

Johnsen, J. T. (1987). Retten til juridisk bistand. Oslo: Tano.

Johnsen, J. T. (1994). Nordic legal aid. Maryland Journal of Contemporay Legal Issues, 5(2), 301-331.

Juss-Buss. (2001). Tvers igjennom lov til seier. Oslo: Unipax. 
Juss-Buss and O. H. Rønning (2011). Med loven mot makta: Juss-Buss førti år. Oslo: Novus Forlag.

Kristiansen, B. L. (2009). Retshjalp i Danmark. Delrapport I: Beskrivelse af retshjalpstilbuddene. Copenhagen: Justitsministeriets forskningsrapport.

Kristiansen, B. L. (2013). Retshjælp - fortsat et udækket behov? In T. Gammeltoft, I. E. Koch, B. L. Kristiansen, \& S. Schaumburg-Müller (Eds.), Protecting the rights of others (pp. 83-101). København: DJØF-Forlag.

Kvist, J., \& Greve, B. (2011). Has the Nordic welfare model been transformed? Social Policy and Administration, 45(2), 146-160.

Lewis, P. (1973). Social needs and legal action. In P. Morris, R. White, \& P. Lewis (Eds.), Social needs and legal action. Oxford: Martin Roberston.

Mathiesen, T. (1975). Noen konlusjoner om rettshjelp, rettspolitikk og samfunnsstruktur. In A. Eidesen, S. Eskeland, \& T. Mathiesen (Eds.), Rettshjelp og samfunnsstruktur (pp. 187-206). Oslo: Pax.

Mathiesen, T. (2001). Juss-Buss 30 år. In Juss-Buss (Ed.), Tvers igjennom lov til seir (pp. 16-19). Oslo: Pax Forlag.

Olesen, A., Minke, L. K., \& Hammerslev, O. (2016). Det retlige møde. In Festskrift til Sten Schaumburg-Müller. København: Jurist- og Økonomforbundets Forlag.

Olesen, A., Nielsen, S.P.P. \& Hammerslev, O. (2017). 'Gadejura - kunsten at fremelske gadefolkets oplevelse af at bære rettigheder.' In B.O.G. Mortensen et al. (Eds.), Festskrift til Hans Viggo Godsk Pedersen. København: Jurist- og Økonomforbundets Forlag.

Papendorf, K. (2012). Rett for alle? Rettsliggjøring og rettsferne personers mulighet til a mobilisere retten. Oslo: Novus forlag.

Piana, D., Langbroek, P., Berkmanas, T., Hammerslev, O., \& Pacurari, O. (Eds.). (2013). Legal and judicial training in Europe. The Hague: Eleven International Publishing.

Pleasence, P., Buck, A., Goriely, T., Taylor, J., Perkins, H., \& Quirk, H. (2001). Local legal need. London: Legal Services Research Centre.

Qin, Z., \& Tang, J. (2013). Practical exploration and thoughts on model of clinical legal education-legal aid. In W. Du (Ed.), Informatics and management science IV (pp. 469-476). London: Springer London.

Sarat, A., \& Scheingold, S. A. (1998). Cause lawyering: Political commitments and professional responsibilities, Oxford socio-legal studies. New York/Oxford: Oxford University Press.

Sejr, L. (Ed.). (1977). Retshjalp i et lokalområde. Aarhus: Aarhus Universitet. 
Smith, R.H. (1919). Justice and the poor: A study of the present denial of justice to the poor and of the agencies making more equal their position before the law, with particular reference to legal aid work in the United States. Carnegie Foundation for the Advancement of Teaching.

Sommerlad, H. (2001). "I've lost the plot": An everyday story of the 'political' legal aid lawyer. Journal of Law and Society, 28(3), 335-360.

Sommerlad, H., \& Sanderson, P. (2013). Social justice on the margins: The future of the not for profit sector as providers of legal advice in England and Wales. Journal of Social Welfare and Family Law, 35(3), 305-327.

Sommerlad, H., \& Wall, D. (1999). Legally aided clients and their solicitors: Qualitative perspectives on quality and legal aid. London: The Law Society.

Open Access This chapter is distributed under the terms of the Creative Commons Attribution 4.0 International License (http://creativecommons.org/ licenses/by/4.0/), which permits use, duplication, adaptation, distribution, and reproduction in any medium or format, as long as you give appropriate credit to the original author(s) and the source, a link is provided to the Creative Commons license, and any changes made are indicated.

The images or other third party material in this book are included in the work's Creative Commons license, unless indicated otherwise in the credit line; if such material is not included in the work's Creative Commons license and the respective action is not permitted by statutory regulation, users will need to obtain permission from the license holder to duplicate, adapt or reproduce the material.

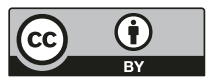

